\title{
Clustering Wilayah Dan Pelanggaran Berkendaraan Menggunakan Algoritma K-Means Pada Data Satlantas Polres Tasikmalaya Kota
}

\author{
${ }^{1}$ Evi Dewi Sri Mulyani, ${ }^{2}$ Agus Maulana Yusup,${ }^{3}$ Alif Kurnia Tisna, ${ }^{4}$ Fahmi Akbar Fauzi, \\ ${ }^{5}$ Irawan Bayu Seta, ${ }^{6}$ Rizky Khairunas, ${ }^{7}$ Wendi Ardiansyah \\ STMIK Tasikmalaya \\ Program Studi Teknik Informatika \\ Jl. RE Martadinata No. 272 A Telp/Fax (0265) 310830 Indihiang Tasikmalaya \\ Email: eviajadech@gmail.com ${ }^{1}$, agusmy3@gmail.com ${ }^{2}$, alifkurniatisna@gmail.com ${ }^{3}$ \\ akbarfauzif@gmail.com ${ }^{4}$, irawanbayuseta@outlook.com ${ }^{5}$, khairunas299@gmail.com 6 , \\ wendiardiansyah66@gmail.com ${ }^{7}$
}

\begin{abstract}
Abstrak
Banyaknya pengguna jalan yang tidak mematuhi peraturan berlalu lintas dengan baik, setiap harinya dapat menambah tingkat kecelakaan dan pelanggaran tata tertib lalu lintas dalam berkendara pada wilayah Kota Tasikmalaya, sehingga masyarakat kurang dalam memahami ketertiban dijalan raya. Penelitian ini menerapkan data mining dengan menggunakan metode clustering pada data pelanggaran lalu lintas Polres Tasikmalaya Kota, algoritma yang digunakan yaitu K-Means clustering berupa proses pengelompokan sejumlah data atau objek ke dalam cluster atau group sehingga setiap dalam cluster tersebut akan berisi data yang semirip mungkin dan berbeda dengan objek dalam cluster lainnya. Data pelanggaran lalu lintas Polres Tasikmalaya kota ini diproses melalui Knowledge Data Discovery (KDD) sehingga dapat diketahui pengujian dengan rapidminer, menghasilkan cluster-cluster pelanggaran lalu lintas. Sampel yang digunakan di ambil dari tabel data pelanggaran lalu lintas yang telah ditrasformasikan. Dimana atribut yang ditentukan sebanyak 6 atribut yaitu wilayah, tidak menggunakan helm, sabuk keselamatan, melanggar rambu lintas, tidak membawa sim dan stnk dan kelebihan muatan. Dimana akan mempresentasikan cluster-cluster tiap kelompok wilayah dan jenis pelanggaran lalu lintas.
\end{abstract}

Kata Kunci : Data Pelanggaran Lalu Lintas, K-Means Clustering, Rapidminer

\begin{abstract}
The number of road users who do not comply with traffic regulations properly every day can increase the level of accidents and violations of traffic rules in driving in the Tasikmalaya City area, so that the community is lacking in understanding order on the highway. This research applies data mining by using clustering methods on data traffic violations in Tasikmalaya City Police, the algorithm used is K-Means clustering in the form of a process of grouping a number of data or objects into clusters or groups so that each cluster will contain data as closely as possible and different from objects in other clusters. The data on the Tasikmalaya Police Precinct traffic violations are processed through Knowledge Data Discovery $(K D D)$ so that it can be known to test with rapidminer, resulting in clusters of traffic violations. The sample used is taken from the data table of traffic violations that have been transformed. Where the attributes specified are 6 attributes, namely region, do not use a helmet, safety belt, violate cross signs, do not carry sim and stnk and overload. Where will present the clusters of each regional group and type of traffic violations.
\end{abstract}

Keywords: Traffic Violation Data, K-Means Clustering, Rapidminer 


\section{PENDAHULUAN}

Transportasi darat merupakan suatu kebutuhan yang tidak bisa dijauhkan dari kalangan masyarakat baik perorangan ataupun kelompok, untuk diketahui sejumlah kendaraan yang beredar dikalangan masyarakat kini dari tahun ke tahun semakin meningkat. Angka kemacetan dan terutama pelanggaran lalu lintas terjadi dimana-mana di daerah Kota Tasikmalaya terutama pada simpang-simpang kota. Banyaknya pengguna jalan yang tidak mematuhi peraturan berlalu lintas dengan baik, setiap harinya dapat menambah tingkat kecelakaan dan pelanggaran tata tertib lalu lintas dalam berkendara pada wilayah Kota Tasikmalaya.

Dikarenakan banyaknya tumpukan data pelanggaran lalu lintas di wilayah hukum Polres Tasikmalaya Kota, setiap tahunnya yang hanya data tersebut diproses ke dalam microsoft excell sehingga membuat data tidak beraturan. Data yang sudah masuk hanya diproses secara manual sehingga menyulitkan pihak kepolisian lalu lintas untuk mengetahui wilayah mana saja dan jenis pelanggaran berkendaraan yang sering melakukan pelanggaran. Maka dari itu di perlukan suatu pengelompokan pelanggaran berkendaraan dengan data-data pelanggaran berkendaraan tersebut yang akan menjadi variabel adalah wilayah dan jenis pelanggaran apa saja yang dilakukan.

Algoritma k-means dapat mengklaster wilayah pada pelanggaran dalam berkendara berdasarkan banyak, sedang dan sedikit wilayah yang melakukan jenis pelanggaran dalam berkendara[1]. Mengambil data-data penting yang tersembunyi dan dikelola kembali menjadi informasi yang akan dikelompokan berdasarkan kriteria atau variabel tersebut. Sehingga dapat dihasilkan seluruh pengetahuan hubungan terdekat data-data pelanggaran berkendara tersebut[2]. Cluster yang terbentuk menghasilkan pengetahuan terkait kasus perkara lalu lintas dan bisa digunakan sebagai kelas target pada teknik klasifikasi[3].

Penerapan data mining pada data pelanggaran lalu lintas untuk mengetahui pelanggaran dan daerah yang sering melanggar serta dilakukan analisa data tersebut dengan clustering dan algoritma k-means[4]. Analisis cluster berguna dalam meringkas data atau sejumlah variabel untuk menjadi lebih sedikit. Dalam melakukan proses data ini dapat dilakukan dengan mengelompokan objek-objek berdasarkan kesamaan karakteristik tertentu diantara objek-objek yang hendak diteliti[5]. Pada penelitian sebelumnya dengan algoritma K-Means dapat menampilkan pengelompokkan kemampuan siswa pada mata pelajaran Ujian Nasional, juga dapat digunakan untuk memantau perkembangan kemampuan setelah mengikuti pengayaan materi[6].

Berdasarkan uraian diatas, maka penelitian ini akan mengolah data pelanggaran lalu lintas tahun 2018 dengan menggunakan algoritma k-means. Dengan begitu tools atau implementasi hasil data pelanggaran lalu lintas dengan Rapidminer,sehingga dapat diketahui wilayah mana saja yang sering melanggar lalu lintas dan jenis pelanggaran apa saja yang dilanggar oleh para pengemudi di daerah Kota Tasikmalaya.

\section{METODE PENELITIAN}

Metode yang digunakan dalam penelitian ini adalah metode deskriptif analisis dengan pendekatan kuantitatif, yaitu penelitian yang kemudian diolah dan dianalisis untuk diambil kesimpulan. Berikut ini adalah kerangka penelitian clustering wilayah dan pelanggaran berkendaraan menggunakan algoritma k-means pada data Satlantas Polres Tasikmalaya Kota :

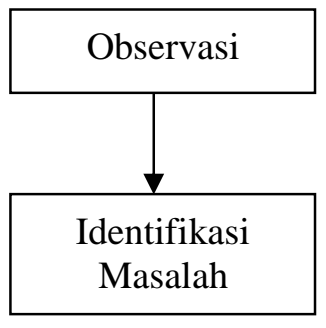




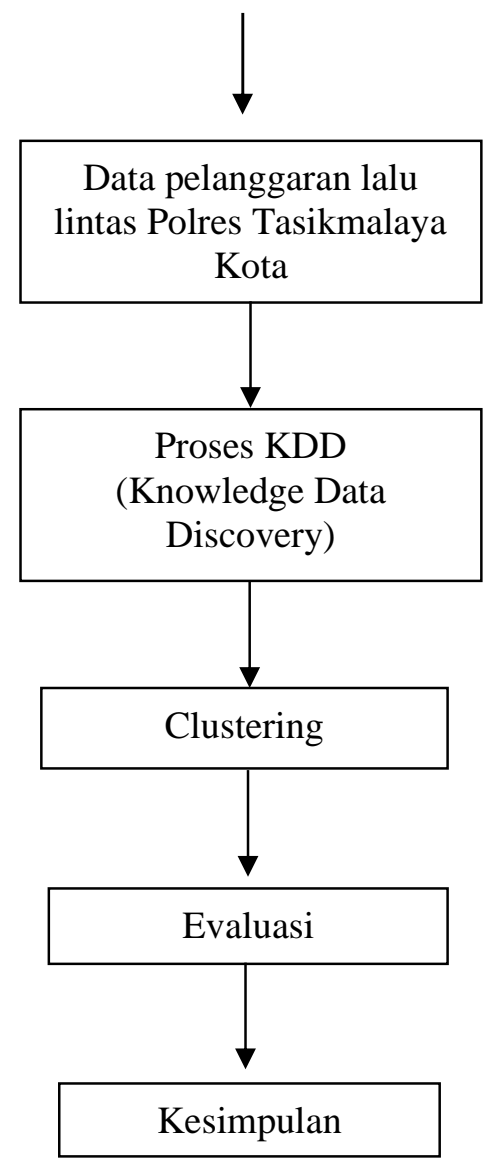

Gambar 1.Kerangka penelitian

K-means clustering merupakan salah satu metode cluster analysis non hirarki yang berusaha untuk mempartisi objek yang ada kedalam satu atau lebih cluster atau kelompok objek berdasarkan karakteristiknya, sehingga objek yang mempunyai karakteristik yang sama dikelompokan dalam satu cluster yang sama dan objek yang mempunyai karakteristik yang berbeda dikelompokan kedalam cluster yang lain [7]. Jarak antara data dan pusat cluster dihitung menggunakan Euclidian Distance. Untuk menghitung jarak semua data ke setiap titik pusat cluster dapat menggunakan teori jarak Euclidean yang dirumuskan sebagai berikut:

$$
D(i, j)=\sqrt{\left(X_{1 i}-X_{1 j}\right)^{2}+\left(X_{2 i}-X_{2 j}\right)^{2}+\ldots+\left(X_{k i}-X_{k j}\right)^{2}}
$$

dimana:

$\mathrm{D}(\mathrm{i}, \mathrm{j})=$ Jarak data ke $\mathrm{i}$ ke pusat cluster $\mathrm{j}$

Xki = Data ke i pada atribut data ke $\mathrm{k}$

$\mathrm{Xkj} \quad=$ Titik pusat $\mathrm{ke} \mathrm{j}$ pada atribut $\mathrm{ke} \mathrm{k}$

\section{HASIL DAN PEMBAHASAN}

\subsection{Sumber Data}

Data yang digunakan dalam penelitian ini adalah dataset pelanggaran lalu lintas Tahun 2018 pada data Satlantas Polres Tasikmalaya Kota. Data yang digunakan berjumlah 343 yang akan diproses melalui tahapan KDD (Knowledge Data Discovery). Berikut ini adalah dataset dari 343 pelanggaran lalu lintas Tahun 2018 : 


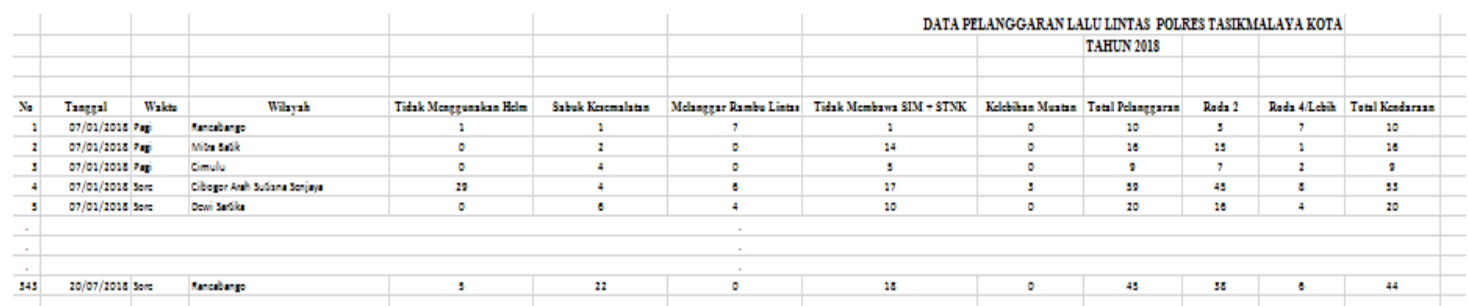

Tabel 1. Dataset Pelanggaran Lalu Lintas

\subsection{Pemilihan Data}

Pada tahap ini dataset pelanggaran lalu lintas tahun 2018 melalui pemilihan data yang semua dataset pelanggaran lalu lintas berjumlah 343 akan dihilangkan melalui data wilayah yang sama dan total jenis pelanggaran menurut wilayah yang sama serta tidak terdapat pada data pelanggaran lalu lintas tahun 2018 yang tidak valid atau missvalue pada proses pemilihan data.

\subsection{Transformasi Data}

Transformasi data dilakukan dilakukan untuk mengubah data tujuannya adalah agar data dapat diolah dengan menggunakan metode K-means Clustering. Adapun atribut yang di gunakan pada data pelanggaran lalu lintas yaitu wilayah, tidak menggunakan helm, sabuk keselamatan, melanggar rambu lintas, tidak membawa SIM+STNK, dan kelebihan muatan. Dalam menstranformasikan data pelanggaran lalu lintas digabungkan berdasarkan wilayah yang sama, dan total jenis pelanggaran menurut wilayah yang sama, sehingga jumlah dataset berjumlah 24. Berikut ini adalah sampel 5 dataset dari 24 pelanggaran lalu lintas Tahun 2018 setelah di transformasikan :

\begin{tabular}{|l|r|r|r|r|r|r|}
\hline Wilayah & Tidak Menggunakan Hel Sabuk Kesemalata Melanggar Rambu Linti Tidak Membawa SIM + STN Kelebihan Muatan \\
\hline Baypass & 8 & 112 & 2 & 4 \\
\hline Bojong Jengkol Arah Leuwidahu & 6 & 45 & 9 & 0 \\
\hline Bypass & 0 & 0 & 1 & 0 \\
\hline Cibogor Arah Ciamis & 0 & 32 & 4 & 0 \\
\hline Cibogor Arah M.Hatta & 62 & 153 & 211 & 84 \\
\hline
\end{tabular}

Tabel 2. Penggabungan Dataset Pelanggaran Lalu Lintas

\subsection{Pengolahan Data}

Pengolahan data pelanggaran lalu lintas dilakukan setelah proses transformasi sehingga data pelanggaran lalu lintas baru bisa diolah menggunakan metode clustering dengan algoritma k-means. Adapaun langkah -langkah perhitungan manual adalah sebagai berikut :

\section{a. Menentukan jumlah cluster}

Diketahui jumlah cluster adalah 3 dikarenakan untuk mengetahui wilayah mana saja yang sering banyak sering terjadi pelanggaran lalu lintas, wilayah yang paling jarang terjadi dan jarang terjadi pelanggaran lalu lintas. Jumlah data adalah 24 dikarenakan telah dilakukan proses transformasi data dengan melalui penggabungan menurut wilayah yang sama dan total jenis pelanggaran wilayah yang sama menjadi 24 dataset. Jumlah atribut yaitu 6 , sama halnya seperti jumlah data yang telah ditransformasikan. 


\begin{tabular}{|c|c|c|c|c|c|c|}
\hline No & Wilayah & $\begin{array}{c}\text { Tidak } \\
\text { Menggun } \\
\text { akan } \\
\text { Helm }\end{array}$ & $\begin{array}{c}\text { Sabuk } \\
\text { Kesemala } \\
\text { tan }\end{array}$ & $\begin{array}{c}\text { Melangg } \\
\text { ar Rambu } \\
\text { Lintas }\end{array}$ & $\begin{array}{c}\text { Tidak } \\
\text { Membaw } \\
\text { a SIM + } \\
\text { STNK }\end{array}$ & $\begin{array}{c}\text { Kelebihan } \\
\text { Muatan }\end{array}$ \\
\hline 1 & Baypass & B & 112 & 2 & 4 & \\
\hline 2 & Bojong Jengkol Arah Leuwidahu & 6 & 45 & 9 & 27 & o \\
\hline 3 & Bypass & 0 & 0 & 1 & 0 & o \\
\hline 4 & Cibogor Arah Ciamis & 0 & 32 & 4 & 84 & o \\
\hline 5 & Cibogor Arah M. Hatta & 62 & 153 & 211 & 174 & 4 \\
\hline 6 & Cibogor Arah Sutisna Senjaya & 39 & 6 & 66 & 40 & 3 \\
\hline 7 & Clembang arah cikurubuk & 0 & 20 & 4 & 35 & 2 \\
\hline$B$ & Cimulu & 6 & 38 & B & 29 & 6 \\
\hline 9 & Dewi Sartika & 34 & 93 & 56 & 57 & o \\
\hline 10 & Dewi Sartika Arah Masjid Agung & 0 & 162 & 29 & 39 & o \\
\hline 11 & Jati & 10 & 17 & 21 & B & 3 \\
\hline 12 & Leuwidahu Arah Bojong Jengkol & 14 & 192 & 4 & 207 & 1 \\
\hline 13 & Leuwidahu Arah Jati & 3 & 135 & 247 & 128 & \\
\hline 14 & Masjid Agung & 72 & 87 & 52 & 107 & 6 \\
\hline 15 & Mitra Batik & 14 & 204 & 120 & 104 & o \\
\hline 16 & Rancabango & 11 & 139 & 85 & 208 & \\
\hline 17 & Simpang Lima & 39 & 93 & 18 & 48 & 4 \\
\hline 18 & Sutisna senjaya arah pancasila & 0 & 3 & 6 & 0 & o \\
\hline 19 & Taman Alun-Alun & 25 & 173 & 31 & 178 & 13 \\
\hline 20 & Taman Kota & 28 & 16 & 34 & 65 & 22 \\
\hline 21 & Wasita Kusuma & 5B & 195 & 71 & 270 & 1 \\
\hline 22 & Wasita Kususma Arah Bandung & 28 & 212 & 115 & 305 & 3 \\
\hline 23 & Wasita Kususma Arah Bojong Jengkol & 2 & 51 & 150 & 169 & 3 \\
\hline 24 & Wasita Kususma Arah Letnan Harun & 16 & 95 & 117 & 229 & 0 \\
\hline
\end{tabular}

Tabel 3. Pengabungan Dataset Pelanggaran Lalu Lintas

b. Menentukan awal pusat cluster

\begin{tabular}{|c|c|c|c|c|c|}
\hline Wilayah & $\begin{array}{c}\text { Tidak } \\
\text { Menggun } \\
\text { akan } \\
\text { Helm }\end{array}$ & $\begin{array}{c}\text { Sabuk } \\
\text { Kesemala } \\
\tan \end{array}$ & $\begin{array}{c}\text { Melangg } \\
\text { ar Rambu } \\
\text { Lintas }\end{array}$ & $\begin{array}{c}\text { Tidak } \\
\text { Membaw } \\
\text { a SIM + } \\
\text { STNK }\end{array}$ & $\begin{array}{c}\text { Kelebihan } \\
\text { Muatan }\end{array}$ \\
\hline \multicolumn{6}{|l|}{ Iterasi 1} \\
\hline Bojong Jengkol Arah Leuwidahu & 6 & 45 & 9 & 27 & 0 \\
\hline Leuwidahu Arah Bojong Jengkol & 14 & 192 & 4 & 207 & 1 \\
\hline Wasita Kusuma & 58 & 195 & 71 & 270 & 1 \\
\hline
\end{tabular}

\section{c. Perhitungan Jarak Pusat Cluster}

Untuk mengukur jarak antara dengan pusat cluster digunakan Euclidian Distance dengan rumus :

$$
D(i, j)=\sqrt{\left(X_{1 i}-X_{1 j}\right)^{2}+\left(X_{2 i}-X_{2 j}\right)^{2}+\ldots+\left(X_{k i}-X_{k j}\right)^{2}}
$$

Sehingga didapatkan C1, C2 dan C3 :

\begin{tabular}{|c|c|c|c|c|c|c|c|c|c|}
\hline & & & & & & & C1 & $\mathrm{c} 2$ & c3 \\
\hline 1 & Baypass & 8 & 112 & 2 & 4 & 0 & 71,21095 & $218,28 B B$ & $291,38 B 1$ \\
\hline 2 & Bojong Jengkol Arah Leuwidahu & 6 & 45 & 9 & 27 & 0 & 0 & 232,5919 & 296,8131 \\
\hline 3 & Bypass & 0 & 0 & 1 & 0 & 0 & 53,42284 & 282,6995 & 345,239 \\
\hline 4 & Cibogor Arah Ciamis & 0 & 32 & 4 & 84 & 0 & 58,98305 & 202,3018 & 262,7147 \\
\hline 5 & Cibogor Arah M. Hatta & 62 & 153 & 211 & 174 & 4 & 277,9011 & 218,5681 & 174,9428 \\
\hline 6 & Cibogor Arah Sutisna Senjaya & 39 & 6 & 66 & 40 & 3 & 77,69813 & 258,7624 & 298,3471 \\
\hline 7 & Cilembang arah cikurubuk & 0 & 20 & 4 & 35 & 2 & 27,45906 & 243,6493 & 306,1111 \\
\hline 8 & Cimulu & 6 & 38 & 8 & 29 & 6 & 9,486833 & 235,595 & 299,0451 \\
\hline 9 & Dewi Sartika & 34 & 93 & 56 & 57 & 0 & 78,72103 & 188,1648 & 237,855 \\
\hline 10 & Dewi Sartika Arah Masjid Agung & 0 & 162 & 29 & 39 & 0 & 119,4529 & 173,0491 & 244,0881 \\
\hline 11 & Jati & 10 & 17 & 21 & 8 & 3 & 36,24914 & 265,5843 & 324,2468 \\
\hline 12 & Leuwidahu Arah Bojong Jengkol & 14 & 192 & 4 & 207 & 1 & 232,5919 & 0 & 101,9951 \\
\hline 13 & Leuwidahu Arah Jati & 3 & 135 & 247 & 128 & 3 & 273,7937 & 262,0382 & 240,3518 \\
\hline 14 & Masjid Agung & 72 & 87 & 52 & 107 & 6 & 120,0208 & 163,4564 & 197,0152 \\
\hline 15 & Mitra Batik & 14 & 204 & 120 & 104 & 0 & 208,7942 & 155,5956 & 178,8155 \\
\hline 16 & Rancabango & 11 & 139 & 85 & 208 & 1 & 217,7131 & 96,8504 & 96,87621 \\
\hline 17 & Simpang Lima & 39 & 93 & 18 & 48 & 4 & 62,69769 & 189,5046 & 250,7329 \\
\hline 18 & Sutisna senjaya arah pancasila & 0 & 3 & 6 & 0 & 0 & 50,37857 & 280,6617 & 342,5697 \\
\hline 19 & Taman Alun-Alun & 25 & 173 & 31 & 178 & 13 & 200,4969 & 46,8615 & 108,5403 \\
\hline 20 & Taman Kota & 28 & 16 & 34 & 65 & 22 & 62,27359 & 229,5147 & 277,0848 \\
\hline 21 & Wasita Kusuma & 58 & 195 & 71 & 270 & 1 & 296,8131 & 101,9951 & 0 \\
\hline 22 & Wasita Kususma Arah Bandung & 28 & 212 & 115 & 305 & 3 & 341,9093 & 150,0833 & 65,98485 \\
\hline 23 & Wasita Kususma Arah Bojong Jengkol & 2 & 51 & 150 & 169 & 3 & 200,2648 & 206,855 & 200,7934 \\
\hline 24 & Wasita Kususma Arah Letnan Harun & 16 & 95 & 117 & 229 & 0 & 234,6657 & 150,5556 & 124,7477 \\
\hline
\end{tabular}




\section{d.Pengelompokan Data}

Jarak hasil perhitungan akan dilakukan perbandingan dan dipih jarak terdekat antara data dengan pusat cluster, jarak ini menunjukan bahwa data tersebut berada dalam satu kelompok dengan pusat clsuter terdekat. Berikut ini data matriks pengelompokan data, nilai 1 berarti data tersebut berada dalam kelompok data :

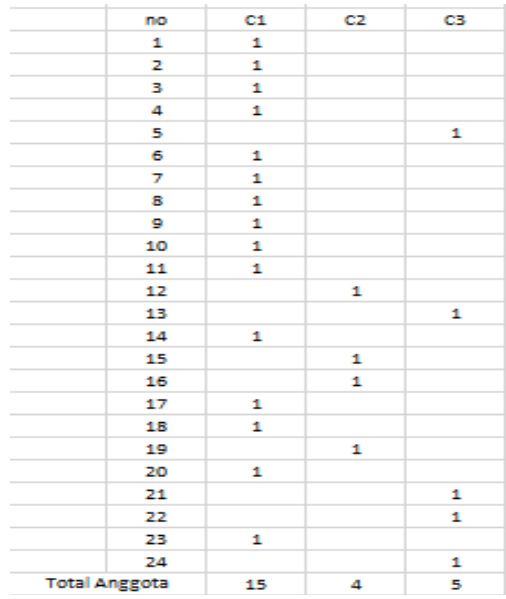

Kelompok Data Ke-1

Selanjutnya pada iterasi 2 dan seterusnya dengan menghitung pusat cluster baru dan mengelompokan data seperti iterasi 1 , sehingga didapatkan nilai pusat setiap cluster sebagai berikut :

\begin{tabular}{|c|c|c|c|c|c|c|}
\hline & Nama Pusat Cluster & $\begin{array}{c}\text { Tidak } \\
\text { Menggun } \\
\text { akan } \\
\text { Helm }\end{array}$ & $\begin{array}{c}\text { Sabuk } \\
\text { Kesemal } \\
\text { atan }\end{array}$ & $\begin{array}{c}\text { Melangg } \\
\text { ar Rambu } \\
\text { Lintas }\end{array}$ & $\begin{array}{c}\text { Tidak } \\
\text { Membaw } \\
\text { a SIM + } \\
\text { STNK }\end{array}$ & $\begin{array}{l}\text { Kelebiha } \\
\text { n Muatan }\end{array}$ \\
\hline \multirow{3}{*}{ Iterasi 1} & Bojong Jengkol Arah Leuwidahu & 6 & 45 & 9 & 27 & 0 \\
\hline & Leuwidahu Arah Bojong Jengkol & 14 & 192 & 4 & 207 & 1 \\
\hline & Wasita Kusuma & 58 & 195 & 71 & 270 & 1 \\
\hline \multirow{3}{*}{ Iterasi 2} & $\mathrm{C} 1$ & 16,26667 & 51,66667 & 30,66667 & 47,46667 & 3,266667 \\
\hline & $\mathrm{C} 2$ & 16 & 177 & 60 & 174,25 & 3,75 \\
\hline & $\mathrm{C} 3$ & 33,4 & 158 & 152,2 & 221,2 & 2,2 \\
\hline \multirow{3}{*}{ Iterasi 3} & $\mathrm{C} 1$ & 17,28571 & 51,71429 & 22,14286 & 38,78571 & 3,285714 \\
\hline & $\mathrm{C} 2$ & 16 & 177 & 60 & 174,25 & 3,75 \\
\hline & $\mathrm{C} 3$ & 28,16667 & 140,1667 & 151,8333 & 212,5 & 2,333333 \\
\hline \multirow{3}{*}{ Iterasi 4} & $\mathrm{C} 1$ & 17,28571 & 51,71429 & 22,14286 & 38,78571 & 3,285714 \\
\hline & $\mathrm{C} 2$ & 24,4 & 180,6 & 62,2 & 193,4 & 3,2 \\
\hline & $\mathrm{C} 3$ & 22,2 & 129,2 & 168 & 201 & 2,6 \\
\hline \multirow{3}{*}{ Iterasi 5} & $\mathrm{C} 1$ & 17,28571 & 51,71429 & 22,14286 & 38,78571 & 3,285714 \\
\hline & $\mathrm{C} 2$ & 25 & 185,8333 & 71 & 212 & 3,166667 \\
\hline & $\mathrm{C} 3$ & 20,75 & 108,5 & 181,25 & 175 & 2,5 \\
\hline
\end{tabular}

Setelah didapatkan nilai pusat cluster baru serta pengelompokan data, sampai data sudah tidak ada lagi yang berpindah ke cluster 1, 2 dan 3. Sehingga proses iterasi pun berhenti pada iterasi ke 5 sebagai beikut :

\section{a. Menentukan pusat cluster baru}

\begin{tabular}{|c|c|c|c|c|c|c|}
\hline & Wilayah & $\begin{array}{c}\text { Tidak } \\
\text { Menggun } \\
\text { akan } \\
\text { Helm }\end{array}$ & $\begin{array}{c}\text { Sabuk } \\
\text { Kesemala } \\
\tan \end{array}$ & $\begin{array}{c}\text { Melangg } \\
\text { ar Rambu } \\
\text { Lintas }\end{array}$ & $\begin{array}{c}\text { Tidak } \\
\text { Membaw } \\
\text { a SIM + } \\
\text { STNK }\end{array}$ & $\begin{array}{c}\text { Kelebihan } \\
\text { Muatan }\end{array}$ \\
\hline & \multirow[t]{2}{*}{ Iterasi 5} & & & & & \\
\hline & & 1 & 2 & 3 & 4 & 5 \\
\hline $\mathrm{Cl}$ & & 17,28571 & 51,71429 & 22,14286 & 38,78571 & 3,285714 \\
\hline $\mathrm{Cl}_{2}$ & & 25 & 185,8333 & 71 & 212 & 3,166667 \\
\hline $\mathrm{C3}$ & & 20,75 & 108,5 & 181,25 & 175 & 2,5 \\
\hline
\end{tabular}




\section{b. Perhitungan jarak pusat cluster baru}

\begin{tabular}{|c|c|c|c|c|c|c|c|c|c|}
\hline & & & & & & & C1 & $\mathrm{c} 2$ & c3 \\
\hline 1 & Baypass & 8 & 112 & 2 & 4 & 0 & 73,12433 & 231,8952 & 248,098 \\
\hline 2 & Bojong Jengkol Arah Leuwidahu & 6 & 45 & 9 & 27 & 0 & 22,24596 & 241,4002 & 236,284 \\
\hline 3 & Bypass & 0 & 0 & 1 & 0 & 0 & 70,25177 & 291,57 & 274,4524 \\
\hline 4 & Cibogor Arah Ciamis & 0 & 32 & 4 & 84 & 0 & 55,42328 & 212,5388 & 214,4473 \\
\hline 5 & Cibogor Arah M. Hatta & 62 & 153 & 211 & 174 & 4 & 257,3103 & 153,2701 & 67,6027 \\
\hline 6 & Cibogor Arah Sutisna Senjaya & 39 & 6 & 66 & 40 & 3 & 66,97993 & 249,2891 & 205,7842 \\
\hline 7 & Cilembang arah cikurubuk & 0 & 20 & 4 & 35 & 2 & 40,61699 & 252,8736 & 243,4761 \\
\hline 8 & Cimulu & 6 & 38 & 8 & 29 & 6 & 24,87161 & 244,2984 & 237,7638 \\
\hline 9 & Dewi Sartika & 34 & 93 & 56 & 57 & 0 & 58,92996 & 181,5463 & 173,3021 \\
\hline 10 & Dewi Sartika Arah Masjid Agung & 0 & 162 & 29 & 39 & 0 & 111,891 & 181,3727 & 212,0734 \\
\hline 11 & Jati & 10 & 17 & 21 & 8 & 3 & 46,96203 & 269,8995 & 249,1127 \\
\hline 12 & Leuwidahu Arah Bojong Jengkol & 14 & 192 & 4 & 207 & 1 & 219,8211 & 68,39388 & 198,6495 \\
\hline 13 & Leuwidahu Arah Jati & 3 & 135 & 247 & 128 & 3 & 256,2432 & 202,7315 & 86,88858 \\
\hline 14 & Masjid Agung & 72 & 87 & 52 & 107 & 6 & 98,94517 & 152,8759 & 156,303 \\
\hline 15 & Mitra Batik & 14 & 204 & 120 & 104 & 0 & 192,4616 & 120,5241 & 134,0322 \\
\hline 16 & Rancabango & 11 & 139 & 85 & 208 & 1 & 200,6191 & 51,04954 & 106,68 \\
\hline 17 & Simpang Lima & 39 & 93 & 18 & 48 & 4 & 47,73465 & 196,2644 & 208,2189 \\
\hline 18 & Sutisna senjaya arah pancasila & 0 & 3 & 6 & 0 & 0 & 66,69031 & 286,4997 & 270,0086 \\
\hline 19 & Taman Alun-Alun & 25 & 173 & 31 & 178 & 13 & 185,2651 & 54,93076 & 163,9287 \\
\hline 20 & Taman Kota & 28 & 16 & 34 & 65 & 22 & 50,67851 & 228,4405 & 206,813 \\
\hline 21 & Wasita Kusuma & 58 & 195 & 71 & 270 & 1 & 279,3577 & 67,3923 & 173,3555 \\
\hline 22 & Wasita Kususma Arah Bandung & 28 & 212 & 115 & 305 & 3 & 324,4979 & 106,2013 & 179,0367 \\
\hline 23 & Wasita Kususma Arah Bojong Jengkol & 2 & 51 & 150 & 169 & 3 & 183,1323 & 163,7042 & 68,34197 \\
\hline 24 & Wasita Kususma Arah Letnan Harun & 16 & 95 & 117 & 229 & 0 & 216,9457 & 103,6664 & $85,17702,2,2)$ \\
\hline
\end{tabular}

\section{c. Pengelompokan Data}

Jarak hasil perhitungan akan dilakukan perbandingan dan dipih jarak terdekat antara data dengan pusat cluster, jarak ini menunjukan bahwa data tersebut berada dalam satu kelompok dengan pusat clsuter terdekat. Berikut ini data matriks pengelompokan data, nilai 1 berarti data tersebut berada dalam kelompok data yang tetap berwarna kuning :

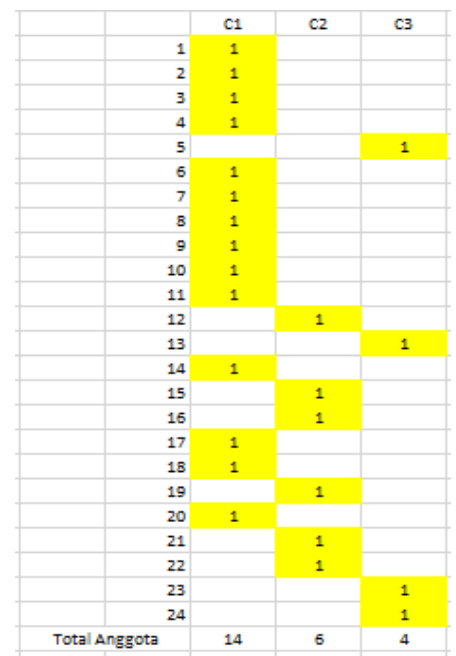

Kelompok Data Ke-5

Dalam penelitian ini proses iterasi terhenti pada iterasi ke 5 karena kondisi cluster sudah mecapai konvergen dan proses iterasi pun berhenti. Sehingga pada iterasi ke 5, titik pusat dari setiap cluster sudah tidak berubah dan tidak ada lagi data yang berpindah dari satu cluster ke cluster yang lain.

\subsection{Implementasi Data Pelanggaran Lalu Lintas Ke Rapidminer}

Adapun pengolahan data pelanggaran lalu lintas dengan menggunakan algoritma k-means clustering dan software Rapidminer dapat dilihat pada gambar berikut : 


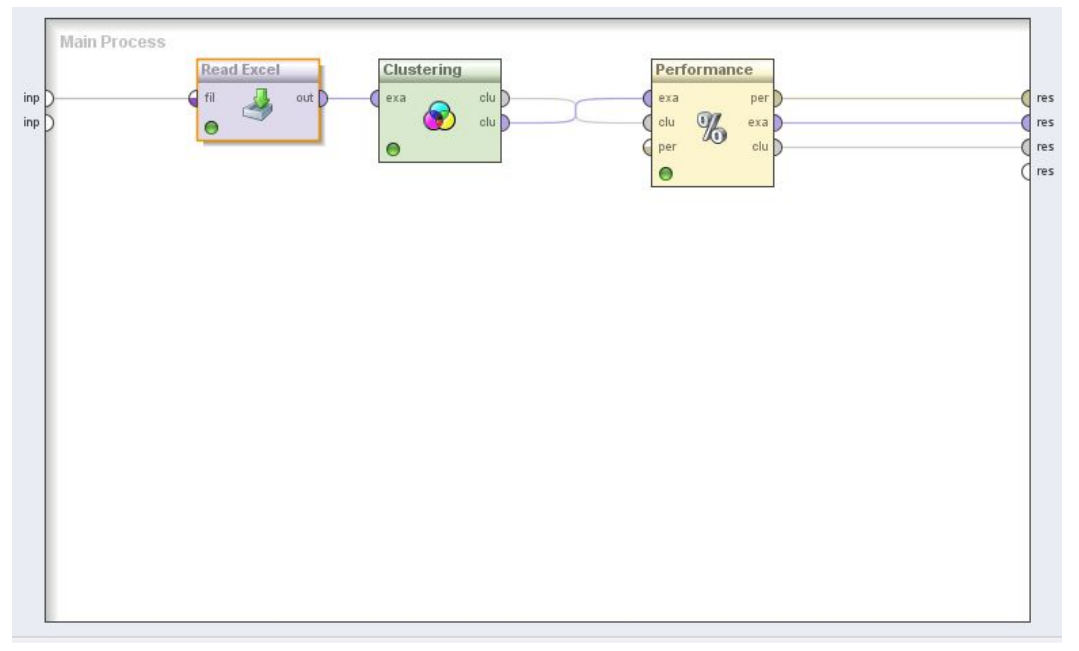

Gambar 2. Pemodelan K-means Pada Rapidminer

Dengan menggunakan pemodelan k-means custering pada gambar 2, maka dengan jumlah data 24 dan inisialisasi jumlah cluster sebanyak 3 buah, sesuai dengan pendefinisian nilai $\mathrm{K}$ dengan jumlah cluster $0: 14$ items, cluster $1: 6$ items, dan cluster 2: items.

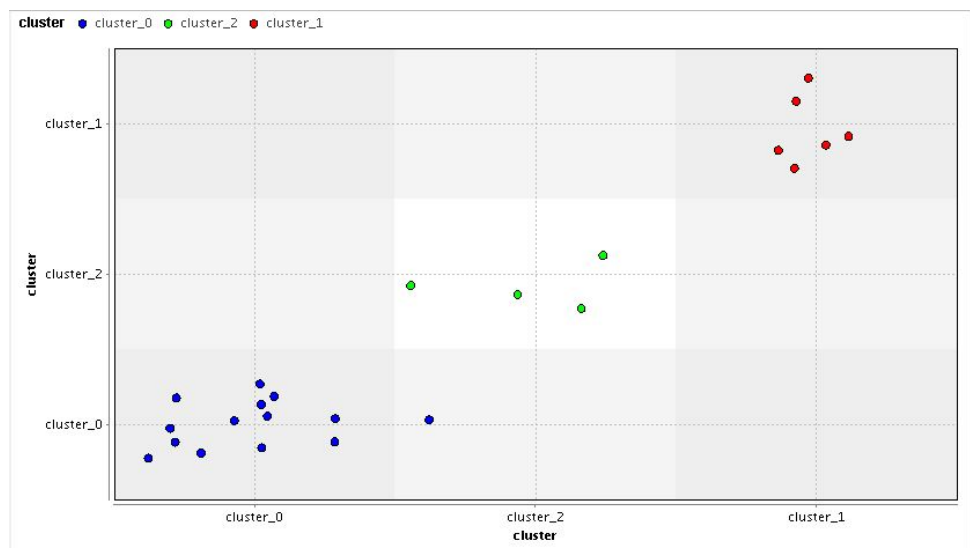

Gambar 3. Exampleshet (Read Excell) Flot view

Merupakan sheet untuk menampilkan database yang telah diolah secara keseluruhan lengkap dengan clusternya, urutan clusternya yaitu cluster_0 terdiri dari 14 titik yang berwarna biru, dengan kelompok 1, 2, 3, 4, 6, 7, 8, 9, 10, 11, 14, 17, 18 dan 20 yang terdiri dari wilayah Bypass, Bojong Jengkol, Bypass, Cibogor Arah Ciamis, Cibogor Arah M.Hatta, Cibogor Arah Sutisna Senjaya, Cilembang Arah Cikurubuk, Cimulu, Dewi Sartika, Dewi Sartika Arah Masjid Agung, Jati, Masjid Agung, Simpang Lima, Sutisna Senjaya Arah Pancasila serta Taman Dadaha. Sedangkan cluster_1 terdiri dari 6 titik berwarna merah dengan kelompok 12, 16, 19, 21, 22 dan 24 yang terdiri dari wilayah Leuwidahu Arah Bojong Jengkol, Rancabango, Taman Alun-Alun, Wasita Kusuma, Wasita Kusuma Arah Bandung, Wasita Kusuma Arah Letnan Harun dan terakhir cluster_2 terdiri dari 4 titik berwarna hijau muda dengan kelompok 5,13,15 dan 23 yang terdiri dari wilayah Cibogor Arah M.Hatta, Leuwidahu Arah Jati, Mitra Batik, Wasita Kusuma Arah Bojong Jengkol. 


\section{Cluster Model}

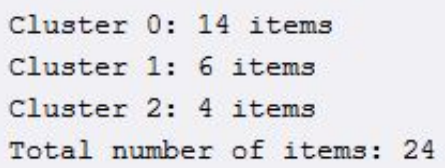

\section{Gambar 4. Cluster Model (Clustering)}

Merupakan sheet untuk menampilkan database yang telah diolah secara keseluruhan dengan Rapidminer, algoritma k-means clustering dengan hasil yang didapatkan yaitu cluster_0 memiliki 14 items kelompok 1, 2, 3, 4, 6, 7, 8, 9, 10, 11, 14, 17, 18 dan 20 yang terdiri dari wilayah Bypass, Bojong Jengkol, Bypass, Cibogor Arah Ciamis, Cibogor Arah M.Hatta, Cibogor Arah Sutisna Senjaya, Cilembang Arah Cikurubuk, Cimulu, Dewi Sartika, Dewi Sartika Arah Masjid Agung, Jati, Masjid Agung, Simpang Lima, Sutisna Senjaya Arah Pancasila serta Taman Dadaha. Sedangkan cluster_1 memiliki 6 items kelompok 12, 16, 19, 21, 22 dan 24 yang terdiri dari wilayah Leuwidahu Arah Bojong Jengkol, Rancabango, Taman Alun-Alun, Wasita Kusuma, Wasita Kusuma Arah Bandung, Wasita Kusuma Arah Letnan Harun serta yang terakhir cluster_2 memiliki 4 items kelompok 5,13,15 dan 23 terdiri dari wilayah Cibogor Arah M.Hatta, Leuwidahu Arah Jati, Mitra Batik, Wasita Kusuma Arah Bojong Jengkol, dengan keseluruhan berjumlah 24 items.

\begin{tabular}{|c|c|c|c|c|c|c|c|c|}
\hline Row No. & Wilayah & ic & cluster & Tidak Meng... & SabukKes... & Melanggar ... & Tidak Mem... & Kelebihan ... \\
\hline 1 & Baypass & 1 & cluster_0 0 & 8 & 112 & 2 & 4 & 0 \\
\hline 2 & Bojong Jengkol Arah Leuwidahu & 2 & cluster_0 & 6 & 45 & 9 & 27 & 0 \\
\hline 3 & Bypass & 3 & cluster_0 & 0 & 0 & 1 & 0 & 0 \\
\hline 4 & Cibogor Arah Ciamis & 4 & cluster_0 0 & 0 & 32 & 4 & 84 & 0 \\
\hline 5 & Cibogor Arah M.Hatta & 5 & cluster_2 & 62 & 153 & 211 & 174 & 4 \\
\hline 6 & Cibogor Arah Sutisna Senjaya & 6 & cluster_0 0 & 39 & 6 & 66 & 40 & 3 \\
\hline 7 & Cilembang arah cikurubuk & 7 & cluster_0 0 & 0 & 20 & 4 & 35 & 2 \\
\hline 8 & Cimulu & 8 & cluster_0 0 & 6 & 38 & 8 & 29 & 6 \\
\hline 9 & Dewi Sartika & 9 & cluster_0 0 & 34 & 93 & 56 & 57 & 0 \\
\hline 10 & Dewi Sartika Arah Masjid Agung & 10 & cluster_0 0 & 0 & 162 & 29 & 39 & 0 \\
\hline 11 & Jati & 11 & cluster_0 & 10 & 17 & 21 & 8 & 3 \\
\hline 12 & Leuwidahu Arah Bojong Jengkol & 12 & cluster_1 & 14 & 192 & 4 & 207 & 1 \\
\hline 13 & Leuwidahu Arah Jati & 13 & cluster_2 & 3 & 135 & 247 & 128 & 3 \\
\hline 14 & Masjid Agung & 14 & cluster_0 0 & 72 & 87 & 52 & 107 & 6 \\
\hline 15 & Mitra Batik & 15 & cluster_2 & 14 & 204 & 120 & 104 & 0 \\
\hline 16 & Rancabango & 16 & cluster_1 & 11 & 139 & 85 & 208 & 1 \\
\hline 17 & Simpang Lima & 17 & cluster_0 & 39 & 93 & 18 & 48 & 4 \\
\hline 18 & Sutisna senjaya arah pancasila & 18 & cluster_0 0 & 0 & 3 & 6 & 0 & 0 \\
\hline 19 & Taman Alun-Alun & 19 & cluster_1 & 25 & 173 & 31 & 178 & 13 \\
\hline 20 & Taman Kota & 20 & cluster_0 0 & 28 & 16 & 34 & 65 & 22 \\
\hline 21 & Wasita Kusuma & 21 & cluster_1 & 58 & 195 & 71 & 270 & 1 \\
\hline 22 & Wasita Kususma Arah Bandung & 22 & cluster_1 & 28 & 212 & 115 & 305 & 3 \\
\hline 23 & Wasita Kususma Arah Bojong Jengkol & 23 & cluster_2 & 2 & 51 & 150 & 169 & 3 \\
\hline 24 & Wasita Kususma Arah Letnan Harun & 24 & cluster_1 & 16 & 95 & 117 & 229 & 0 \\
\hline
\end{tabular}

Gambar 5. Tampilan Examplset DataView

Merupakan sheet untuk menampilkan database yang telah diolah secara keseluruhan lengkap dengan cluster berjumlah 24 items. Sehingga dapat diketahui kelompok cluster_0, cluster_1 dan cluster_2.

\subsection{Evaluasi}

Berdasarkan hasil dari proses KDD (Knowledge Data Discovery) dapat di evaluasi bahwa pada perhitungan algoritma k-means clustering menggunakan perhitungan manual menggunakan microsoft excell dengan dataset berjumlah 24 setelah di transformasikan, bahwa 
menghasilkan iterasi 1 sampai 5, dengan hasil akhir pada iterasi 5 pun berhenti sehingga diketahui jumlah clsuter 3 yaitu cluster_1 berjumlah 14 anggota kelompok $1,2,3,4,6,7,8,9,10,11,14,17,18$ dan 20, cluster_2 berjumlah 6 anggota kelompok 12,15,16,19,21 dan 22 , cluster_3 berjumlah 4 anggota kelompok 5,13,23 dan 24.

Implementasi data pelanggaran lalu lintas ke rapidminer menghasilkan 3 cluster yaitu cluster_0 memiliki 14 items kelompok 1, 2, 3, 4, 6, 7, 8, 9, 10, 11, 14, 17, 18 dan 20 yang terdiri dari wilayah Bypass, Bojong Jengkol, Bypass, Cibogor Arah Ciamis, Cibogor Arah M.Hatta, Cibogor Arah Sutisna Senjaya, Cilembang Arah Cikurubuk, Cimulu, Dewi Sartika, Dewi Sartika Arah Masjid Agung, Jati, Masjid Agung, Simpang Lima, Sutisna Senjaya Arah Pancasila serta Taman Dadaha. Sedangkan cluster_1 memiliki 6 items kelompok 12, 16, 19, 21, 22 dan 24 yang terdiri dari wilayah Leuwidahu Arah Bojong Jengkol, Rancabango, Taman Alun-Alun, Wasita Kusuma, Wasita Kusuma Arah Bandung, Wasita Kusuma Arah Letnan Harun serta yang terakhir cluster_2 memiliki 4 items kelompok 5,13,15 dan 23 terdiri dari wilayah Cibogor Arah M.Hatta, Leuwidahu Arah Jati, Mitra Batik, Wasita Kusuma Arah Bojong Jengkol, dengan keseluruhan berjumlah 24 items. Sehingga kedua hasil tersebut sama antara perhitungan menggunakan microsoft excell dan rapidminer dengan cluster_0 berjumlah 14, cluster_1 berjumlah 6 dan cluster_2 berjumlah 4.

\section{KESIMPULAN}

Berdasarkan uraian yang telah dikemukakan pada bab-bab sebelumnya, maka dapat ditarik beberapa kesimpulan sebagai berikut :

1. Algoritma k-means clustering dapat diterapkan pada data pelanggaran lalu lintas Polres Tasikmalaya Kota, sehingga metode ini dapat membantu dalam mengelompokan data jenis pelanggaran lalu lintas.

2. Hasil perhitungan menggunakan microsoft excell dan rapidminer menghasilkan 3 cluster yaitu cluster_0 memiliki 14 items kelompok 1, 2, 3, 4, 6, 7, 8, 9, 10, 11, 14, 17, 18 dan 20 terdiri dari wilayah Bypass, Bojong Jengkol, Bypass, Cibogor Arah Ciamis, Cibogor Arah M.Hatta, Cibogor Arah Sutisna Senjaya, Cilembang Arah Cikurubuk, Cimulu, Dewi Sartika, Dewi Sartika Arah Masjid Agung, Jati, Masjid Agung, Simpang Lima, Sutisna Senjaya Arah Pancasila serta Taman Dadaha. Sedangkan cluster_1 memiliki 6 items kelompok 12, 16, 19, 21, 22 dan 24 terdiri dari wilayah Leuwidahu Arah Bojong Jengkol, Rancabango, Taman Alun-Alun, Wasita Kusuma, Wasita Kusuma Arah Bandung, Wasita Kusuma Arah Letnan Harun serta yang terakhir cluster_2 memiliki 4 items kelompok 5,13,15 dan 23 terdiri dari wilayah Cibogor Arah M.Hatta, Leuwidahu Arah Jati, Mitra Batik, Wasita Kusuma Arah Bojong Jengkol, dengan keseluruhan berjumlah 24 items.

\section{DAFTAR PUSTAKA}

[1] Fajariyanti, W. (2017). Clustering Wilayah Pada Pelanggaran Berkendaraan Menggunakan Metode K-Means (Studi Kasus:Polres Kediri), Sikmi-Techsain, Vol 01, No.09

[2] Ramadhani, N., Rahman, A. F., \& Riskiyati, D. (2017). Analisis Cluster Data Register Perkara Lalu Lintas Menggunakan Algoritma K-Means. SESINDO 9, 2017.

[3] Delita Buaton ${ }^{1)}$ Fitri Nurhayati ${ }^{2)}$ "Clustering Pelanggaran Berkendaraan Menggunakan Algoritma K-Means Pada Polres Binjai", Jurnal STMIK Kaputama.

[4] Lestian Cahya Ardianata ${ }^{1)}$ Ahmad Zainul Fanani ${ }^{22}$ "Implementasi Algoritma K-Means Pada Data Pelanggaran Lalu Lintas Di Pengadilan Negeri Purwodadi”, Jurnal UDINUS, Semarang.

[5] Handoko, K. (2016). Penerapan Data Mining dalam Meningkatkan Mutu Pembelajaran 
Menggunakan Metode K-MEANS Clustering. Jurnal Nasional Teknologi dan Sistem Informasi, 2(3), 31-40.

[6] Mulyani, E. D. S., Agustin, Y. H., Surgawi, N. M., \& Susanto, S. (2018). Implementasi Algoritma K-Means Dan Fp-Growth Untuk Rekomendasi Bimbingan Belajar Berdasarkan Segmentasi Akademik Siswa. IT (Informatic Technique) Journal, 6(2), 160-173.

[7] Agus Nur Khomarudin "Algoritma K-Means Clustering”, Ilmu Komputer, 2016. 